\title{
Clinical Considerations in Otorhinolaryngology Practice in COVID-19 Pandemic Era
}

\author{
Soo Ah Son and Se Hwan Hwang $(\mathbb{D}$ \\ Department of Otolaryngology-Head and Neck Surgery, Bucheon St. Mary's Hospital, College of Medicine, \\ The Catholic University of Korea, Seoul, Korea
}

\author{
코로나바이러스감염증-19의 대유행 시기에서 이비인후과 진료 시에 필요한 임상적인 고려사항들 \\ 손수아 · 황세환 \\ 가톨릭대학교 의과대학 부천성모병원 이비인후과학교실
}

\author{
Received March 12, 2021 \\ Revised May 25, 2021 \\ Accepted May 27, 2021 \\ Address for correspondence \\ Se Hwan Hwang, MD, PhD \\ Department of Otolaryngology- \\ Head and Neck Surgery, \\ Bucheon St. Mary's Hospital, \\ College of Medicine, \\ The Catholic University of Korea, \\ 327 Sosa-ro, Bucheon 14647, Korea \\ Tel $+82-32-340-7044$ \\ Fax $+82-32-340-2674$ \\ E-mail yellobird@catholic.ac.kr
}

The coronavirus disease 2019 (COVID-19) epidemic originated in Wuhan, China and spread rapidly worldwide, leading the World Health Organization to declare an official global COVID-19 pandemic in March 2020. The upper aero-digestive tract is known to be the highest viral load reside. The infection spreads via droplets or direct contact with contaminated surfaces via aeorsol. The otolaryngologists deal with diseases of the upper-aerodigestive tract and routinely are engaged in respiratory droplet and aerosol-generating procedures (AGP). In particular, because airborne transmission occurs during examination and AGP, otolaryngologists are considered to be at a high risk of contracting COVID-19 during this pandemic. Therefore otolaryngologists need to do precautions to protect staff and patients and minimize transmission of the disease. We also need to wear adequate personal protective equipment according to the examination and procedure. This article discusses the disease transmission and clinical characteristics of COVID-19 as well as precaution guidelines in outpatient clinics of otorhinolaryngology. Korean J Otorhinolaryngol-Head Neck Surg 2021;64(5):297-303

Key Words Aerosols · COVID-19 · Otorhinolaryngology · Personal protective equipment · Viral load.

\section{서 론}

중증급성호흡기증후군 코로나바이러스2(severe acute respiratory syndrome coronavirus 2, SARS-CoV-2)의 출현 은 2019년 12월 중국 우한에서 신종 코로나바이러스(2019$\mathrm{nCoV}$ )가 분리되면서 처음 보고되었고, 2020년 3월 11일에 WHO는 coronavirus disease 2019(2019년 코로나바이러스 질병, COVID-19)를 대유행으로 선포했다. ${ }^{1)}$ SARS-CoV-2는 기존에 유행하였던 severe acute respiratory syndrome(SARS) 및 Middle East respiratory syndrome(MERS)과 같은 코로

This is an Open Access article distributed under the terms of the Creative Commons Attribution Non-Commercial License (https://creativecommons.org/licenses/by-nc/4.0) which permits unrestricted non-commercial use, distribution, and reproduction in any medium, provided the original work is properly cited.
나바이러스에 속하여, 독감 유사 증상에서 시작하며, 하기도 질환인 폐렴으로 진행되는 비슷한 임상적인 양상을 보인다. 하지만 치사율 및 전파 양상에서는 차이점을 보이는데, SARS 와 MERS는 비교적 10 30\%의 높은 치사율과 낮은 확산 속 도를 보인데 반하여, COVID-19는 전파 속도가 매우 빨라 두 바이러스가 확산되었던 속도보다 더 빠르게 전 세계로 확 산되어, 대유행이 진행되고 있는 현재까지 전 세계적으로 1.5 억 명 이상이 COVID-19에 확진되었고 3 백만 명 이상이 사 망하였다.2)

특히 바이러스의 전파시기는 호흡기에서 바이러스의 양이 가장 높은 것과 일치하는데, SARS-CoV와 MERS의 경우에 전파가 일어나는 시기는 임상증상 발생 수일 후에서 발생 10 일경인데 반하여, COVID-19의 경우에는 임상증상 발생 직 
후에 바이러스의 양이 가장 많았고, 이후 증상 발생 4일경부 터 점차 감소되는 양상으로 증상 발생 초기 수일 동안에 일 어날 수 있음을 시사한다. 또한 무증상 감염자의 상기도에서 검출된 바이러스 양도 유증상자의 상기도에서 검출된 바이 러스 양과 유사한 것으로 보고되고 있어 SARS-CoV-2의 전 파가 무증상 감염자 또는 증상이 경한 경우에도 바이러스 전 파가 가능할 수 있음을 나타낸다(Table 1). ${ }^{3)}$ 실제로 우리나라 에서의 전파 양상을 고려해 보았을 때, 감염 초기에 주로 전 파가 발생하는 것으로 보여, 증상이 없거나 가벼운 경우에도 환자가 인식하지 못하거나 격리되지 않아서 지역사회 감염을 유발할 수 있는 것으로 나타났다. ${ }^{4,5)}$

다른 호흡기 바이러스와 마찬가지로 비말과 직접 및 간접 접촉을 통해 전파가 일어난다. ${ }^{6}$ 감염자의 비말(침방울)이 호 흡기나 눈·코·입의 점막으로 침투될 때 감염되는 것이 주요 전파 경로로, 통상 비말의 이동거리는 $2 \mathrm{~m}$ 로 알려져 있어 사 회적 거리두기(social distancing)의 기준으로 사용된다. 눈의 경우 환자의 침 등이 눈에 직접 들어가거나, 바이러스에 오염 된 손으로 눈을 비비면 눈을 통해 감염될 수 있다. 또한 2020 년 2월 19일 중국 당국은 비말뿐 아니라 공기 중에 떠 있는 고체 또는 액체 미립자(에어로졸)에 의한 COVID-19의 전파 가능성도 확인하였다. ${ }^{7)}$

바이러스는 지름이 $1 \mu \mathrm{m}(100$ 만분의 $1 \mathrm{~m})$ 에 불과한 에어로 졸 형태로 공기 중에 약 30 분간 떠다니다가 바닥이나 물체에
떨어져 최대 3 시간 생존한다. 이외 구리 표면에서 4시간, 택배 상자와 같은 카드보드에서 24시간, 플라스틱이나 스테인리스 표면에서 72 시간 동안 생존한다. ${ }^{8}$ 이와 같은 결과는 감염자를 치료하는 의료진이 에어로졸로 인한 감염의 위험에 노출될 가능성이 매우 높음을 의미하는 것으로, 병원 내에서 시행되 고 있는 여러 술기(예시, 기관지 삽관이나 심폐소생술 등)의 과정에서 에어로졸과 비말이 상당량 뿜어져 나오며, 의료진의 호흡기로 직접적인 전파 가능성뿐만 아니라 보호장비 표면이 상당량의 바이러스에 오염되므로 보호장비를 벗을 때도 바 이러스에 노출될 위험이 있다.

이러한 에어로졸의 위험성에 대해서 이비인후과 의사들은 보다 주의를 가질 필요가 있는데, 감염력의 지표인 바이러스 의 양을 고려할 때, 증상 발생 후 1 주 이내에 가래보다 상기도 검체에서 바이러스 양이 적어도 2 배 이상 많았고, 비강과 구 강을 비교했을 때에는 비강에서 보다 높은 바이러스 양이 보 고되어 있다. 특히 많은 이비인후과 진찰 및 술기는 상기도를 대상으로 하며 비말 및 에어로졸을 유발하는 것으로 알려져 있다(Table 2). ${ }^{3,9,10)}$

한국, 미국, 중국, 이탈리아, 이란, 영국 등에서는 이비인후 과 의사를 COVID-19의 감염 위험성이 가장 높은 군으로 분 류하고, 외래 혹은 수술 중에 발생할 수 있는 위험성을 고려하 여 적절한 개인 보호장구(personal protective equipments)를 착용해야 한다고 권고하였다. ${ }^{11-17)}$ COVID-19의 대유행이 아

Table 1. Comparison of the transmission pattern of the viruses

\begin{tabular}{llll}
\hline & \multicolumn{1}{c}{ SARS-CoV-2 } & \multicolumn{1}{c}{ SARS-CoV-1 } & MERS-CoV \\
\hline First identified location & Wuhan, China & Guangdong, China & Jeddah, Saudi Arabia \\
Period & 2019-present & $2002-2003$ & $2012-$ ongoing \\
Route of transmission & Contact, droplets, fomites, & Close contact, droplets, & Close contact, zoonotic \\
& airborne \\
Peak viral load from the symptoms onset & $4-5$ th days & $7-10$ th days & 14 th day \\
Case fatality rate & $3.8 \%$ & $9.6 \%$ & $34.4 \%$
\end{tabular}

MERS-COV: Middle Eastern respiratory syndrome coronavirus, SARS-CoV-2: severe acute respiratory syndrome coronavirus 2

Table 2. Summmary of included procedures and recommendation

\begin{tabular}{lcc}
\hline \multicolumn{1}{c}{ Procedure } & Droplet $(\mathrm{Y} / \mathrm{N} /$ potential) & Aerosol generating medical procedure \\
\hline Nasal endoscopy & $Y$ & Potential \\
Nasal packing and treatment of epistaxis & $Y$ & Potential \\
Endoscopic sinonasal and anterior skull base & 1. Powered instrument: $Y$ & 1. Powered instrument: $Y$ \\
surgery & 2. Cold non-powered procedure: $Y$ & 2. Cold non-powered procedure: $\mathrm{N}$ \\
$\mathrm{CO}_{2}$ laser ablation & $\mathrm{Y}$ & $\mathrm{Y}$ \\
Electrocautery & $\mathrm{Y}$ & $\mathrm{Y}$ \\
Tracheostomy & $\mathrm{Y}$ & $\mathrm{Y}$ \\
Endotracheal suctioning & $\mathrm{Y}$ & $\mathrm{Y}$ \\
Oropharyneal surgery and dental procedure & $\mathrm{Y}$ & $\mathrm{Y}$ \\
Mastoid surgery & $\mathrm{Y}$ & $\mathrm{Y}$ \\
Nasal nebulizer/atomizer & $\mathrm{Y}$ & $\mathrm{N}$ \\
\hline
\end{tabular}


직도 지속되는 가운데, 적절한 이비인후과적인 진료가 시행되 면서도 의료진의 안전 및 전파 방지는 매우 중요한 사항임을 고려하여 관련 내용들을 기술하고자 한다.

\section{이비인후과 진료실에서의 주의 및 고려사항}

\section{증상과 문진에 따른 선별진료소 환자 분리하기}

COVID-19 대유행 시대에 접어들면서 최근에는 진료 전에 환자에게 반드시 간단한 문진을 통하여 선별진료소에서 검 사를 받아야 할지에 대한 유무를 파악해야 한다. 이비인후과 의사들은 COVID-19 환자로 의심될 만한 소견을 숙지하고 있어야 하며, 신체검사 전에 빠르게 문진하여 의심환자는 선 분류하여 코로나 검사를 받게 해야 한다. 특히 이비인후과 진료를 보는 환자들의 증상이 COVID-19 환자들의 초기 증 상들과 매우 유사한 부분이 많기 때문에 더욱 주의하여야 한 다. ${ }^{18)} \mathrm{COVID}-19$ 임상 증상으로는 발열(체온>37.5 $\mathrm{C}$ ) 혹은 열 감이 있거나, 기침, 가래, 짧은 호흡 및 호흡 곤란과 같은 상기 도 감염 증상이 있으며, 또한 최근 한달 이내에 발생한 후각 장애 혹은 미각 장애가 있거나 식욕부전, 설사, 구토, 복통 등 위장관 증상이 있다. ${ }^{19)}$ 특히 영국 이비인후과학회(ENT UK) 에서는 최근의 COVID-19 감염 후 후각 소실은 진단적 단서 가 될 수 있다고 하였으며, 국내에서도 양성 환자 $30 \%$ 에서 무 후각증(anosmia)이 보고되고 경증 환자에서 주 증상인 경우 가 많았기 때문에 COVID-19 감염증을 의심할 수 있는 높은 진단적 가치를 가지는 것으로 생각된다. ${ }^{20)}$ 당장 응급 처치가 필요하지 않은 환자들을 제외하고, 앞서 말한 증상을 동반한 환자들은 진료 전에 선별진료소를 통한 정밀 진료가 우선시 되어야 한다. 추가적으로 최소 15 분 이상, $1 \mathrm{~m}$ 이내에 $\mathrm{COV}-$ ID-19 환자와 접촉한 과거력이 있거나 역학적 연관성이(최근 14 일 이내에 확진 환자와 접촉력, 최근 14 일 이내에 COVID-19 지역 전파가 있는 국가 방문 혹은 최근 14일 이내에 '국 내 집단 발생'과 역학적 연관성이 분명한 경우) 있는 환자 또 한 선별진료소를 통한 COVID-19 검사가 필요하다. ${ }^{20,21)}$

\section{진료실 내에서 보호장구 관련 고려 사항}

앞서 기술된 문진 및 선별진료소로 완전히 COVID-19를
배제할 수 없으며, 검사의 위양성, 무증상 환자 등을 고려할 때 진료실 내에서도 의료진 및 대기 중인 환자들의 보호를 위 한 주의가 필요하다. ${ }^{22)}$ 특히 비말 및 에어로졸을 유발하는 진 찰이나 술기가 많은 이비인후과 진료 시에는 의료진의 안전 및 전파 방지를 위해 의료진은 적절한 보호장구 착용이 권고 되고, 술기를 할 때 에어로졸을 발생할 수 있는 여러 상황에 유의하며 가급적 최소한으로 진행해야 한다. 개인 보호장구 단계를 설정하여 술기의 위험도에 따라 알맞은 단계에 속하 는 보호장구를 착용하도록 추천한다(Table 3). ${ }^{18)}$ 에어로졸을 유발하지 않으나 비말의 유발 가능성이 있는 비강과 구강 내 단순 시진 혹은 귀, 코, 목에 대해 시진 및 단순 촉진만 필요 한 환자, 이경 검사 및 현미경 검사 등 직접적인 접촉이 필요 없는 환자, 혹은 단순 내과적 약물치료만 필요한 추적관찰 환 자 같은 경우에는 1 단계의 보호장구 착용[personal protective equipment(PPE) level 1]만으로 충분할 것이다. ${ }^{21,23)}$ 그러 나 후두내시경, 비내시경, 비강 혹은 구강 분무기 사용, 전기 소작술, 레이저 시술, 기관 절개술, 기관루를 통한 각종 술기 는 이비인후과에서 흔히 하는 시술로 비말과 에어로졸을 모 두 유발할 수 있기 때문에 2단계의 보호장구 착용이 필요하 다(Fig. 1). ${ }^{7,24)}$ 단, 에어로졸을 유발하는 시술이라도 시술 시 간이 짧을 경우 2 단계 보호장구로 충분하지만 오래 걸리는 시술 사례나 고위험군의 진료 시에는 3단계 보호장구까지 착 용이 필요하다. ${ }^{718)}$

\section{진료실 내에서 처치 및 술기 관련 고려 사항}

Table 2에서 기술된 바와 같이 사용되는 술기에서 발생하 는 비말 및 에어로졸의 유무에 따라 적절한 개인 보호장구의 단계설정이 필요하고, 대부분 외래에서 내시경을 통한 진찰을 시행하는 경우에는 2 단계의 보호장구 착용(PPE level 2)이 권고된다. ${ }^{25)}$ 진료실에서 흔히 쓰이는 벤츄리 원리를 적용한 분무기(예시, 에피네프린 스프레이 혹은 리도카인 스프레이) 는 주로 구강이나 비강의 점막에 국소적인 마취제 혹은 혈관 수축제 같은 국소적 약물투여를 위해 사용된다. 하지만, 비강 과 같이 점차 가늘어지는 공간에 분무기를 분사하게 될 경우 에는 압축된 공기 흐름이 강하게 반동되는 경향이 있기 때문 에 반동된 공기 흐름은 에어로졸과 결합되어 분무기의 끝에 쉽게 오염될 수 있고, 이를 다시 분사하게 되면 주변부 또한

Table 3. PPE levels for otorhinolaryngologist

PPE level 1 Surgical mask, gown, gloves, face shield or goggles, head cover (optional)

PPE level 2 N95/FFP2, water impermeable gown, double gloves, goggles/face shield and head cover, including neck protection PPE level 3 Powered air-purifying respirators or N95/FFP2 + surgical mask, gowns (1. coverall plus gown with integrated hood and boots is preferred 2. water-impermeable gown), double gloves, goggles + (face shield), head cover, including neck protection

PPE: personal protective equipment 


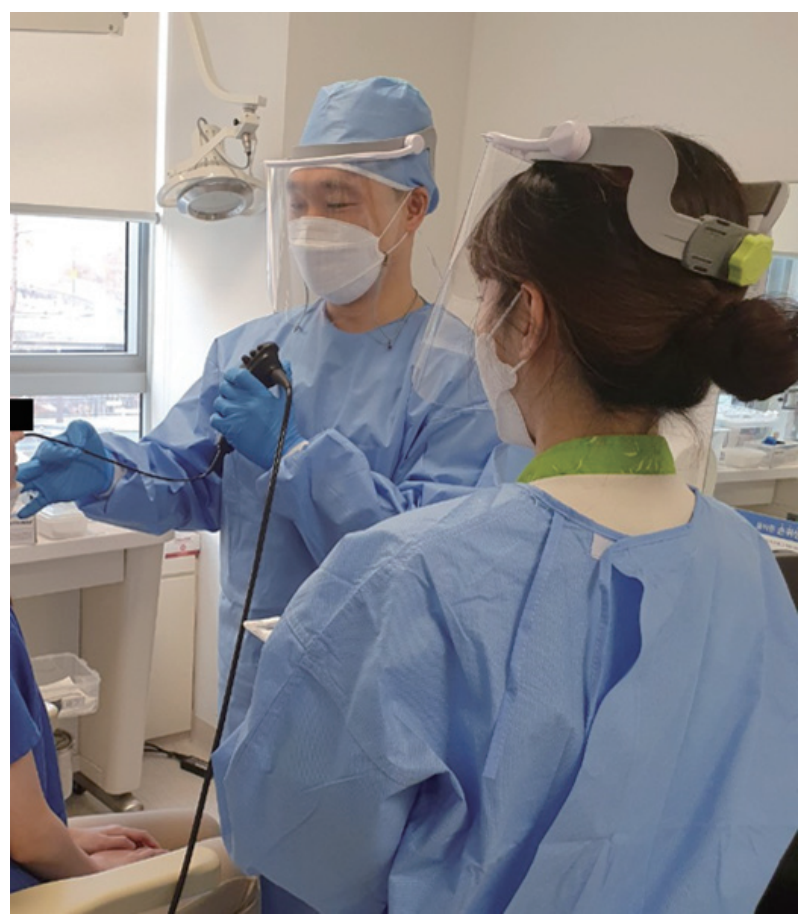

Fig. 1. Practice of the medical staffs wearing personal protective equipment in the outpatient clinic.

오염이 퍼질 수 있다. 21,26) 또한 분무기 사용 자체도 환자로부 터 재채기와 기침을 유발할 수 있기 때문에 에어로졸에 의해 감염이 일어날 수 있다.27) 그렇기 때문에 COVID-19 대유행 을 고려할 때 외래에서 분무기를 사용하는 것은 가급적 지 양해야 하며, 대신 국소 마취 혹은 지혈을 위해서 비강 내 거 즈 활용이 권장되고 있다. ${ }^{7}$

후두내시경이나 비내시경은 이비인후과 핵심 술기로 자주 사용된다. 내시경 자체는 자발적으로 에어로졸을 생성하는 술기는 아니지만, 이로 인해 환자에게 기침과 재채기 혹은 구 역질을 유발하기 때문에 에어로졸을 형성하여 감염의 경로가 될 수 있다. ${ }^{23)}$ 이에 두경부 혹은 비과 진료를 하는 이비인후과 의사들은 2단계의 보호장구를 착용하도록 권고되고 있다.) 기존의 내과적인 질환으로 인해 혹은 반복적으로 다량으로 발생하는 코피 환자들 같은 경우에는, 코 안 팩킹을 시행하거 나 전기 소작술을 시행하게 된다. 팩킹은 삽입뿐만 아니라 제 거 시의 통증이나 자극으로 인하여 불수의적 기침을 유발하 게 되어 에어로졸에 의한 바이러스 전파를 일으킬 수 있다. ${ }^{21}$ 전기 소작술은 조직의 열 분해를 일으켜 연기를 발생시키고 바이러스나 미생물의 전파 가능성이 있다. ${ }^{28)}$ 이와 같은 문제 점들을 고려하여 국소 에피네프린 거즈나 화학적 소작술이 우선 조심스럽게 고려되고, 이후에도 지혈이 되지 않는 경우 양극성 전기소작기(bipolar electrocautery)나 팩킹을 해야하 는 경우에는 처치를 최소화하기 위한 흡수성 충전물질을 사
용하도록 추천한다. ${ }^{29)}$ 입 안이나 코 점막안에 발생한 병변에 대해서 외래에서 조직검사를 시행할 경우에도 전기 소작술을 사용할 수 있으며, 인후두 내 병변에 대해서는 수술 방에서 $\mathrm{CO}_{2}$ 레이저를 이용한 시술을 하기도 한다. 전기 소작술이나 레이저 시술은 모두 감염 전파 가능성이 있는 에어로졸과 연 기를 생성할 수 있다. ${ }^{7)}$ 시술 시 2단계의 개인 보호장구 착용 이 권고되며 흡인기(suction)를 사용하여 지속적으로 공기를 흡입하게 되면 효과적으로 많은 양의 에어로졸 등을 제거할 수 있는 것으로 알려져 있다. 기관절개술을 하는 경우, 그리고 절개된 기관을 통해서 흡인 혹은 술기를 진행할 경우도 비말 및 에어로졸에 노출될 위험성이 매우 높다. ${ }^{18,23)}$ 그렇기 때문 에 최소 2 단계 이상의 보호장구를 착용해야 하며, 응급 환자 여서 감염 위험성에 대한 정보를 모르는 경우에는 양성 환자 에 준해서 개인 보호장구 3 단계를 착용하고 술기를 진행해 야 한다. ${ }^{21}$

\section{이비인후과 질환 관련 처방 시에 고려 사항}

전신 혹은 국소 스테로이드는 이비인후과의 다양한 질환에 서 사용되고 있으나, 면역 억제 등의 기전으로 인해서 감염 질 환이 동반된 경우에서는 사용에 주의해야 하는 것으로 알려 져 있다. 특히 전신 스테로이드 투여의 경우, 기존의 연구들에 서 인플루엔자, SARS 및 MERS와 같은 바이러스 감염 질환 에서 관련 사망률을 증가시키거나 체외로의 바이러스 ribonucleic acid 배출 억제, 스테로이드 자체의 합병증을 유발하 는 것으로 보고하였고, 이로 인해서 사용하지 않도록 권고하 고 있다. ${ }^{30)}$ 우한에서 발표된 COVID-19로 입원 치료한 환자 들의 데이터 분석을 보면, 전신 저용량 스테로이드는 환자의 사망률에 영향을 미치지는 않았으나 전신 고용량 스테로이드 ( $\geq 1 \mathrm{mg} / \mathrm{kg} /$ day prednisone 혹은 $\geq 0.15 \mathrm{mg} / \mathrm{kg} /$ day dexamethasone)의 경우는 통계학적으로 유의하게 사망률을 높 이는 것을 알 수 있었다. ${ }^{31}$

이러한 내용들을 고려하여, 돌발성 난청이나 메니에르병의 경우에는 전신 스테로이드 사용 대신 국소 고실 내 주입술을 시행하도록 하고 있다. ${ }^{32)}$ 하지만 벨마비의 경우에는 조기에 스테로이드 치료(prednisolone, $\mathrm{mg} / \mathrm{kg}$ a day for the first 5 days, tapered thereafter)를 하는 경우, 진행되는 신경의 부 종을 미연에 방지하여 더 이상의 신경 손상을 최소화하여, 영 구적 안면신경마비의 발생 빈도를 감소시키는 것으로 알려져 있다. ${ }^{33)}$ 특히 Ramsey 등 ${ }^{34}$ 이 메타분석을 통해 보고한 바와 같이 안면 근육의 마비가 생기고 일주일 안에 적절한 경구 스 테로이드 치료를 한 경우 완전 회복률이 약 $71 \%$ 에서 $88 \%$ 로 증가한다고 보고된 바 있다. 이는 현재 전신 스테로이드 치료 가 대체하기는 어려우며, 최근 영국 이비인후과 가이드라인에 
Table 4. Precaution for procedures with high risk of COVID-19 transmission in the ENT examination room

Procedures Advice

\begin{tabular}{ll}
\hline Nasal or laryngeal endoscopy & $\begin{array}{c}\text { Avoid using local decongestant and anesthetics in form of spray. Apply the intranasal pledge } \\
\text { carefully for the endoscopic examination. } \\
\text { Use monitor system instead of the eyepiece during endoscopic examination. } \\
\text { Epistaxis management }\end{array}$ \\
$\begin{array}{l}\text { Avoid electrical cauterization if possible (potential to transmit virus via smoke), use chemical } \\
\text { cauterization instead. }\end{array}$ \\
$\begin{array}{l}\text { If the removal is challenging (because of location or intolerable patients), conduct the removal } \\
\text { under general anesthesia. }\end{array}$
\end{tabular}

서도 COVID-19가 음성임을 확인한 이후 전신 스테로이드 치료를 시작할 것을 권고하고 있다. ${ }^{35)}$

현재 국소 스테로이드에 대해서는 COVID-19와 관련된 임 상 연구는 발표되지 않았으나, 기관지 상피세포와 COVID-19 를 함께 배양한 세포 연구에서 ciclesonide를 투여 시에 상피 세포에서 interleukin(IL)-6와 IL-8 등 사이토카인의 분비를 감소시켜 조직 손상을 낮추고 세포 내에서 바이러스의 증식 을 억제하는 것으로 보고하였다. ${ }^{36)}$ 유럽 이비인후과 학회에서 는 허가된 용량 내의 비강 내 국소 스테로이드 사용이 COVID-19의 감염을 증가시키거나 감염된 환자에서 질병을 악화 시킨다는 근거는 현재 없기 때문에, 알레르기 비염 혹은 만성 부비동염으로 국소 스테로이드를 사용하던 환자는 중단할 필요가 없다고 하였다. 오히려 중단으로 인한 호흡기 염증이 악화되면 기침 혹은 재채기 등으로 인해서 COVID-19의 전 파 가능성이 높아지거나, 만성 부비동염의 악화는 중증 $\mathrm{CO}-$ VID-19의 위험인자인 천식 등을 유발할 수 있음을 언급하였 다. ${ }^{37,38)}$ 현재 COVID-19와 식염수 자가 비강세척에 대한 이중 맹검 무작위 대조군 연구(double blind randomized controlled study)는 없으나 review 등에서 식염수 자가 비강 세척을 통한 비강 내 바이러스 양(viral load)을 줄이고 비강 섬모 운동 및 선천 면역계(innate immune system)를 촉진함으로써 항바 이러스 효과를 가질 것으로 예상하여 경도의 증상 환자들에 게 도움이 될 수 있을 것이라고 언급하였다. ${ }^{39,40)}$

\section{결 론}

이처럼 COVID-19 대유행 시대에 임상적 증상만으로 양성 환자를 판단하기 어렵고, $\mathrm{PCR}$ 검사에서도 무시할 수 없는 위음성률을 보이고 있기 때문에 ${ }^{12)}$ 진료 전 환자군을 적절하 게 분류하고, 환자 진료 시에는 술기의 정도에 따라 진료 지침 및 개인 보호장구 가이드라인의 중요성이 대두되고 있다. 더 욱이 이비인후과 의사는 환자 진료 시 주요 전파 경로인 비말 및 에어로졸로 인한 감염 위험 노출이 높기 때문에, 환자 진 료 시 적절한 처치 및 보호장구 착용은 의료진 자신을 보호 하는 것뿐 아니라, 다른 환자들의 감염 전파 방지를 위한 최
소한의 노력이다. 이에 술자는 각각 술기에 따라서 적절한 보 호장구 및 진료에 대한 내용을 기술하였다(Table 4).

\section{Acknowledgments}

I am grateful that Professor Jun-ook Park in Catholic university of Korea helped us to collect the data regarding the personal protective equipments.

\section{Author Contribution}

Conceptualization: Se Hwan Hwang. Formal analysis: Soo Ah Son. Investigation: Soo Ah Son. Supervision: Se Hwan Hwang. Validation: Se Hwan Hwang. Writing —original draft: Soo Ah Son, Se Hwan Hwang. Writing — review \& editing: Se Hwan Hwang.

\section{ORCID}

Se Hwan Hwang https://orcid.org/0000-0002-2838-7820

\section{REFERENCES}

1) World Health Organiztion. WHO Director-General's opening remarks at the media briefing on COVID-19. 2020 Mar [cited 2020 Aug 23]. Available from: URL: https://www.who.int/directorgeneral/speeches/detail/who-director-general-s-opening-remarksat-the-media-briefing-on-covid-19---11-march-2020.

2) Harapan $H$, Itoh $N$, Yufika $A$, Winardi $W$, Keam $S$, Te H, et al. Coronavirus disease 2019 (COVID-19): A literature review. J Infect Public Health 2020;13(5):667-73.

3) Kowalski LP, Sanabria A, Ridge JA, Ng WT, de Bree R, Rinaldo A, et al. COVID-19 pandemic: Effects and evidence-based recommendations for otolaryngology and head and neck surgery practice. Head Neck 2020;42(6):1259-67.

4) Peiris JS, Chu CM, Cheng VC, Chan KS, Hung IF, Poon LL, et al. Clinical progression and viral load in a community outbreak of coronavirus-associated SARS pneumonia: A prospective study. Lancet 2003;361(9371):1767-72.

5) Park SE. Epidemiology, virology, and clinical features of severe acute respiratory syndrome - coronavirus-2 (SARS-CoV-2; coronavirus disease-19). Clin Exp Pediatr 2020;63(4):119-24.

6) World Health Organiztion. Modes of transmission of virus causing COVID-19: Implications for IPC precaution recommendations. 2020 Mar [cited 2020 Aug 23]. Available from: URL: https://www. who.int/news-room/commentaries/detail/modes-of-transmissionof-virus-causing-covid-19-implications-for-ipc-precautionrecommendations.

7) Thamboo A, Lea J, Sommer DD, Sowerby L, Abdalkhani A, Diamond $\mathrm{C}$, et al. Clinical evidence based review and recommendations of aerosol generating medical procedures in otolaryngology - head and neck surgery during the COVID-19 pandemic. J Otolaryngol Head Neck Surg 2020;49(1):28.

8) van Doremalen N, Bushmaker T, Morris DH, Holbrook MG, Gamble 
A, Williamson BN, et al. Aerosol and surface stability of SARSCoV-2 as compared with SARS-CoV-1. N Engl J Med 2020;382(16): 1564-7.

9) World Health Organization. Advice on the use of masks in the community, during home care and in health care settings in the context of the novel coronavirus $(2019-\mathrm{nCoV})$ outbreak: Interim guidance, 29 January 2020. 2020 [cited 2020 Aug 23]. Available from: URL: https://apps.who.int/iris/handle/10665/330987.

10) World Health Organization. Transmission of SARS-CoV-2: Implications for infection prevention precautions. $2020 \mathrm{Jul}$ [cited 2020 Aug 23]. Available from: URL: https://www.who.int/newsroom/commentaries/detail/transmission-of-sars-cov-2implications-for-infection-prevention-precautions.

11) Zhao C, Viana A Jr, Wang Y, Wei HQ, Yan AH, Capasso R. Otolaryngology during COVID-19: Preventive care and precautionary measures. Am J Otolaryngol 2020;41(4):102508.

12) Liu Z, Zhang L. At the center of the COVID-19 pandemic: Lessons learned for otolaryngology-head and neck surgery in China. Int Forum Allergy Rhinol 2020;10(5):584-6.

13) Ralli M, Mannelli G, Bonali M, Capasso P, Guarino P, Iannini V, et al. Impact of COVID-19 on otolaryngology in Italy: A commentary from the COVID-19 task force of the young otolaryngologists of the Italian Society of Otolaryngology. Eur Rev Med Pharmacol Sci 2020;24(13):7516-8.

14) Sowerby LJ, Stephenson K, Dickie A, Lella FAD, Jefferson N, North $\mathrm{H}$, et al. International registry of otolaryngologist-head and neck surgeons with COVID-19. Int Forum Allergy Rhinol 2020;10(11): 1201-8.

15) Stephenson K, Sowerby LJ, Hopkins C, Kumar N. The UK national registry of ENT surgeons with coronavirus disease 2019. J Laryngol Otol 2020;134(8):665-9.

16) Howard BE, Lal D. Rhinologic practice special considerations during COVID-19: Visit planning, personal protective equipment, testing, and environmental controls. Otolaryngol Head Neck Surg 2020;163(4):676-81.

17) Lee KI, Kim DK, Mo JH. Clinical reviews of COVID-19 for otorhinolaryngologists. J Rhinol 2021;28(1):1-13.

18) Lammers MJW, Lea J, Westerberg BD. Guidance for otolaryngology health care workers performing aerosol generating medical procedures during the COVID-19 pandemic. J Otolaryngol Head Neck Surg 2020;49(1):36.

19) Lavinsky J, Kosugi EM, Baptistella E, Roithmann R, Dolci E, Ribeiro TK, et al. An update on COVID-19 for the otorhinolaryngologist a Brazilian Association of Otolaryngology and Cervicofacial Surgery (ABORL-CCF) Position Statement. Braz J Otorhinolaryngol 2020;86(3):273-80

20) Lee KI, Kim DK, Lee KH, Mo JH, Kim SW. Practical recommendation of COVID-19 for otorhinolaryngologists. J Rhinol 2021;28(1):14-8.

21) Tuli IP, Trehan S, Khandelwal K, Chamoli P, Nagendra S, Tomar A, et al. Diagnostic and therapeutic endonasal rhinologic procedures generating aerosol during COVID-19 pandemic: A systematized review. Braz J Otorhinolaryngol 2020:S1808-8694(20)30229-9.

22) Poggio P, Songia P, Vavassori C, Ricci V, Banfi C, Barbieri SS, et al. Digital PCR for high sensitivity viral detection in false-negative SARS-CoV-2 patients. Sci Rep 2021;11(1):4310.

23) Mick P, Murphy R. Aerosol-generating otolaryngology procedures and the need for enhanced PPE during the COVID-19 pandemic: A literature review. J Otolaryngol Head Neck Surg 2020;49(1):29.
24) Vukkadala N, Qian ZJ, Holsinger FC, Patel ZM, Rosenthal E. COVID-19 and the otolaryngologist: Preliminary evidence-based review. Laryngoscope 2020;130(11):2537-43.

25) Krajewska J, Krajewski W, Zub K, Zatoński T. COVID-19 in otolaryngologist practice: A review of current knowledge. Eur Arch Otorhinolaryngol 2020;277(7):1885-97.

26) Tseng TM, Chen PY, Tseng H, Lin HC, Chang CY, Hung SH. An unexpected route for otolaryngology bacterial contamination with a Venturi atomizer. Rhinology 2014;52(2):156-61.

27) Kohanski MA, Lo LJ, Waring MS. Review of indoor aerosol generation, transport, and control in the context of COVID-19. Int Forum Allergy Rhinol 2020;10(10):1173-9.

28) Chan Y, Banglawala SM, Chin CJ, Côté DWJ, Dalgorf D, de Almeida JR, et al. CSO (Canadian Society of Otolaryngology - Head \& Neck Surgery) position paper on rhinologic and skull base surgery during the COVID-19 pandemic. J Otolaryngol Head Neck Surg 2020; 49(1):81.

29) Chan CPL, Chan JYK. Profiling severe acute respiratory syndrome coronavirus 2 and its relevance to otolaryngologic examinations during the coronavirus disease 2019 pandemic. Curr Opin Allergy Clin Immunol 2021;21(1):38-45.

30) Russell CD, Millar JE, Baillie JK. Clinical evidence does not support corticosteroid treatment for 2019-nCoV lung injury. Lancet 2020;395(10223):473-5.

31) Li X, Xu S, Yu M, Wang K, Tao Y, Zhou Y, et al. Risk factors for severity and mortality in adult COVID-19 inpatients in Wuhan. J Allergy Clin Immunol 2020;146(1):110-8.

32) Lang B, Hintze J, Conlon B. Coronavirus disease 2019 and sudden sensorineural hearing loss. J Laryngol Otol 2020:1-3.

33) Kim MW, Kim J. Early stage steroid treatment for acute facial paralysis in Korea. Korean J Otorhinolaryngol-Head Neck Surg 2016;59(5):346-52.

34) Ramsey MJ, DerSimonian R, Holtel MR, Burgess LP. Corticosteroid treatment for idiopathic facial nerve paralysis: A meta-analysis. Laryngoscope 2000;110(3 Pt 1):335-41.

35) ENTUK. Guidance for ENT during the COVID-19 pandemic. 2020 Mar [cited 2020 Aug 23]. Available from: URL: https://www. entuk.org/guidance-ent-during-covid-19-pandemic.

36) Matsuyama S, Kawase M, Nao N, Shirato K, Ujike M, Kamitani $\mathrm{W}$, et al. The inhaled corticosteroid ciclesonide blocks coronavirus RNA replication by targeting viral NSP15. bioRxiv [Preprint]. 2020 Mar [cited 2021 Mar 12]. Available from: URL: https://doi. org/10.1101/2020.03.11.987016.

37) Klimek L, Jutel M, Bousquet J, Agache I, Akdis CA, Hox V, et al. Management of patients with chronic rhinosinusitis during the COVID-19 pandemic-An EAACI position paper. Allergy 2021; 76(3):677-88.

38) Bousquet J, Akdis C, Jutel M, Bachert C, Klimek L, Agache I, et al. Intranasal corticosteroids in allergic rhinitis in COVID-19 infected patients: An ARIA-EAACI statement. Allergy [serial online] 2020 Mar 31 [cited 2020 Aug 23]; 75(10). Available from: URL: https://onlinelibrary.wiley.com/doi/10.1111/all.14302.

39) Casale M, Rinaldi V, Sabatino L, Moffa A, Ciccozzi M. Could nasal irrigation and oral rinse reduce the risk for COVID-19 infection? Int J Immunopathol Pharmacol 2020;34:2058738420941757.

40) Huijghebaert S, Hoste L, Vanham G. Essentials in saline pharmacology for nasal or respiratory hygiene in times of COVID-19. Eur J Clin Pharmacol 2021:1-19. 


\section{정답 및 해설}

1. 답 (5)

해 설 유전성 출혈성 모세혈관확장증은 상염색체 우성으로 유전되는 질환으로 5000 8000명당 1명에 발생하는 드문 질환이다. Rendu-Osler-Weber disease라고도 불리우며 점막피부와 내부장기의 모세혈관확장증을 특징으로 한다. 여러 기관을 침 범하며, 이비인후과 영역에서는 비점막을 따라 모세혈관확장 소견을 관찰할 수 있다. 진단은 (1) 재발하는 비출혈, (2) 다발성 점막피부 모세혈관확장증, (3) 소화기관, 폐, 간, 뇌와 같은 내장 침범, (4) 1촌의 가족력 중 3가지 이상 해당되면 확진할 수 있으며, 2 가지 이상 해당되면 의증으로 진단된다. $90 \%$ 이상의 환자에서 비출혈이 첫 번째 증상으로 발현된다. 참고 문헌: 최신 임상비과학. 보완판. 파주: 군자출판사;2020. p.154.

2. 답 (1)

해 설 한국인의 비부비동 림프종의 대부분을 차지하는 혈관중심성 림프종은 자연세포독성 $T$ 세포 림프종(NK/T cell lympho$\mathrm{ma}$ )이다. 남녀 성비가 5:1 정도로 남성에서 호발하며, 50대가 호발연령층이다. 보합결합반응(in situ hybridization)에서 Epstein-Barr virus(EBV) 양성 소견을 보여, EBV가 병인에 관여할 것이라 추측되고 있다. 초기에 비폐색과 악취성, 농 성, 혈성 비루, 그리고 가피 형성 등으로 시작하여 조직파괴가 나타난다. 조직생검을 통해 확진하며, 주의할 점은 비정형 세포들이 괴사부위에 흩어져 있어 만성 염증소견만을 보이는 경우가 많으므로 항상 가피 아래에 있는 조직을 채취하는 것이 중요하다. NK/T 세포에 특이적인 표식자로 CD2, CD3, 그리고 CD56, CD57 등이 이용된다.

참고 문헌: 최신 임상비과학. 보완판. 파주: 군자출판사;2020. p.548-9, 841-2. 